\title{
Short communication: The diversity of ureolytic bacteria isolated from limestone in East Java, Indonesia based on amino acid sequences encoded by ureC
}

\author{
ENNY ZULAIKA ${ }^{1, \vartheta}$, M. A. PRIO UTOMO ${ }^{1}$, N. HIDAYATUL ALAMI ${ }^{1}$, N. DWIANITA KUSWYTASARI ${ }^{1}$, \\ MAYA SHOVITRI ${ }^{1}$, RIDHO BAYUAJI ${ }^{2}$, ENDRY N. PRASETYO ${ }^{1}$ \\ ${ }^{1}$ Department of Biology, Faculty of Sciences, Institut Teknologi Sepuluh Nopember. Jl. Arif Rahman Hakim, Sukolilo, Surabaya, East Java, Indonesia. \\ Tel.: +62-31-5947319, Fax.: +62-31-5947319, "email: ennyzulaika123@ gmail.com \\ ${ }^{2}$ Department of Civil Engineering Infrastructure, Faculty of Vocations, Institut Teknologi Sepuluh Nopember. Keputih, Sukolilo, Surabaya 60111, East
} Java, Indonesia.

Manuscript received: 5 February 2019. Revision accepted: 26 July 2019.

\begin{abstract}
Zulaika E, Utomo MAP, Alami NH, Kuswytasari ND, Shovitri M, Bayuaji R, Prasetyo EN. 2019. Short communication: The diversity of ureolytic bacteria isolated from limestone in East Java, Indonesia based on amino acid sequences encoded by ureC. Biodiversitas 20: 2316-2320. Ureolytic bacteria isolated from limestone are capable to produce urease enzyme which can breaks down urea into carbonate $\left(\mathrm{CO}_{3}{ }^{2}\right)$, has been utilized for various building material bioremediation and restoration. In this present study, we figured out the diversity and genetic relationship of $\alpha$ sub-unit ureC gene among six ureolytic bacteria (JA1, JB2, JB3, JA4, AK4, and SU1) which were isolated from limestone area in East Java province. PCR was conducted to detect the gene which encoded active site of urease, ureC. Followed by sequences translation using BLAST-X (Basic Local Alignment Search Tool) based on the name and function of formed proteins and then aligned to the conserved domain database. Furthermore, the functions and characters of formed proteins were described. Based on PCR results, all isolates showed $340 \mathrm{bp}$ DNA band which indicate the presence of ureC gene. The results of BLAST-X, JB2 isolates showed $100 \%$ similarity with the a sub-unit ureC gene from Lysinibacillus sphaericus B1-CDA (WP 054549252.1). Whereas, JA1 isolates showed 88\% similarity (lowest) with the $\alpha$ sub-unit ureC gene from Bacillus cihuensis FJAT-14515 (WP_028391929.1). The present study reveals that ureC phylogeny can be used in order to investigate ureolytic bacteria species which isolated from calcareous area in East Java province.
\end{abstract}

Keywords: Bacteria, diversity, ureC gene, ureolytic

\section{INTRODUCTION}

Calcium carbonate $\left(\mathrm{CaCO}_{3}\right)$ is one of the most abundant materials in nature and main material of cement (Ozen et al. 2013; Jeong et al. 2017). It is massively used for cement-based materials like concrete and mortar because of its remarkable durability (Chunxiang et al. 2009). $\mathrm{CaCO}_{3}$ formation through a biomineralization process generating heterogeneous accumulation which consists of organic and inorganic compounds that reflect the environment where it founds (Skinner and Ehrlich 2014). Bacteria is one of the microorganisms that can induce the biomineralization process of $\mathrm{CaCO}_{3}$ in nature and is widely found in calcareous habitats (Jimenez-Lopez et al. 2008). $\mathrm{CaCO}_{3}$ precipitation which performed by heterotroph bacteria occurs through nitrogen and sulfur cycle. Induction of $\mathrm{CaCO}_{3}$ biomineralization related to sulfur cycle by means of sulfate-reducing bacteria occurs in anoxic conditions (Castanier et al. 1999). While, $\mathrm{CaCO}_{3}$ precipitation related to the nitrogen cycle might occur through the oxidative amino acid deamination process and urea hydrolysis in aerobic conditions. On the other hand, nitrate reduction occurs in anaerobic or microaerophilic conditions (Castanier et al. 1999). However, the biomineralization process of $\mathrm{CaCO}_{3}$ mainly appears through urea hydrolysis process by urease producing bacteria (Hammes et al. 2003; De Jong et al. 2010).

Urease is a metalloenzyme that requires nickel ion to hydrolyze urea into ammonia and carbamate, then it will be spontaneously hydrolyzed to form carbonic acid and the other ammonia molecules (Andrews et al. 1984). Urease from Sporosarcina pasteurii which has been successfully purified and crystallized is heteropolymer protein $(\alpha \beta \gamma)_{3}$ that consists of three polypeptide chains with a molecular weight: $\alpha=61.4 \mathrm{kDa}, \beta=14.0 \mathrm{kDa}$, and $\gamma=11.1 \mathrm{kDa}$ (Benini et al. 1999). The active site contains two nickel ions banded with three to four amino acids (Benini et al. 1999). Urease is encoded by three structural genes: ureA genes encode $\gamma$ subunit, ure $B$ encode $\beta$ subunits, and ure $C$ encode $\alpha$ subunits (Joners and Mobley 1989). Furthermore, there are several additional proteins encoded by accessory genes namely ureD, ureE, ureF, ure $G$, and ureH which contribute in nickel ions transport $\left(\mathrm{Ni}^{2+}\right)$ towards the center of active site of urease (Mobley et al. 1995). ureC gene is the largest gene encoding urease functional subunit and contains many conserved areas. It possesses many priming sites and it can be used as gene marker to study bacterial diversity (Gresham et al. 2007).

Six bacterial isolates JA1, JB2, JB3, JA4, AK4, and SU1 are successfully isolated from calcareous area in East 
Java province, Indonesia (Utomo 2018). Those bacterial isolate showing precipitation zone around their colony when cultivated on $\mathrm{CaCO}_{3}$ precipitation selective media as described by Shiping et al. (2015). The objective of present study is to detect their ureolytic ability in Christensen Agar and determine the diversity and genetic relationship of ure $\mathrm{C}$ gene from $\mathrm{CaCO}_{3}$ forming isolates which isolated from calcareous area in East Java, Indonesia.

\section{MATERIALS AND METHODS}

\section{Materials}

Urease qualitative test was performed on isolates JA1, JB2, JB3, JA4, AK4, and SU1 which originated from Jaddih, Bangkalan and Suci, Gresik lime hills area in the Province of East Java, Indonesia; while AK4 isolated from new stalagmites of Akbar cave, Tuban, East Java, Indonesia (Utomo 2018).

\section{Procedure}

\section{Qualitative urease test}

The morphological characteristics of $\mathrm{CaCO}_{3}$ precipitating bacterial colony from East Java limestone area following Harley and Prescott (2002) protocols are described in Table 1. Urease activity detection was performed by employing Christensen agar which contains urea 20.0; $\mathrm{NaCl} 5.0$; peptone 1.0; glucose 1.0; $\mathrm{KH}_{2} \mathrm{PO}_{4} 2.0$; phenol red 0.012; and agar $15.0(\mathrm{~g} / \mathrm{L})$ according to the protocol of Atlas (2010). All ingredients were sterilized by autoclaving, except $20 \%$ urea solution which sterilized through membrane filtration. Bacterial isolates were incubated at $37^{\circ} \mathrm{C}$ and observed regularly for the production of color. Bacteria that can hydrolyze urea produce cherish pink color after 24 hours incubation.

\section{Genomic DNA extraction and PCR}

DNA template for amplification process from $\mathrm{CaCO}_{3}$ forming isolates was obtained by extracting total genomic DNA in accordance to manufacturers protocol (Qiagen ${ }^{\circledR}$, Germany) with some minor modifications. Amplification of ure $C$ gene was performed in $50 \mu \mathrm{L}$ reaction mixture containing $25 \mu \mathrm{L}$ of OneTaq ${ }^{\circledR}$ Quick-Load $2 \mathrm{X}$ Master Mix with Standard Buffer (New England BioLabs $\left.{ }^{\circledR}, \mathrm{US}\right), 1 \mu \mathrm{L}$ of forwarding ureC-F primer (5'-TGGGCCTTAAAATHC AYGARGAYTGGG-3'), $1 \mu \mathrm{L}$ of ureC-R reverse primer (5'-GGTGGTGGCACACCATNANCATRTC-3 ') (Reeds 2001), $2 \mu \mathrm{L}$ of template DNA, and nuclease-free water until the total volume of reaction mixture reaches $50 \mu \mathrm{L}$. PCR was then performed on the thermocycler under condition: initial denaturation at $94^{\circ} \mathrm{C}$ (30 seconds), followed by 35 cycles consisting of denaturation $\left(94{ }^{\circ} \mathrm{C} ; 30\right.$ seconds), annealing $\left(50^{\circ} \mathrm{C} ; 50\right.$ seconds $)$, extension $\left(68^{\circ} \mathrm{C}\right.$; 1.5 minutes $)$, and final extension $\left(68^{\circ} \mathrm{C} ; 10\right.$ minutes $)$. Electrophoresis was carried out in ThermoFishcer® $1.5 \%$ agarose at voltage $100 \mathrm{~V} / \mathrm{cm}$ for 30 minutes (Caccamo et al. 2001). The 340 bp ure $C$ gene DNA band that appeared was then purified using the AccuPrep® PCR Purification Kit (Bioneer®, South Korea).
Table 1. The morphology of $\mathrm{CaCO} 3$ precipitating bacteria

\begin{tabular}{lccc}
\hline Isolates & Form & $\begin{array}{c}\text { Colony morphology } \\
\text { Elevation }\end{array}$ & Margin \\
\hline JA 1 & Irregular & Flat & Undulate \\
JB 2 & Irregular & Flat & Erose \\
JB 3 & Circular & Convex & Entire \\
JA 4 & Circular & Convex & Entire \\
AK 4 & Irregular & Flat & Erose \\
SU 1 & Irregular & Raised & Erose \\
\hline
\end{tabular}

\section{Sequencing and ureC gene sequence analysis}

The pure ure $C$ gene fragment was sequenced through ABI 3730XL DNA analyzer (Bioneer®, South Korea). Amplicons sequence were then translated into amino acid sequence by using BLASTX. The sequence of deduced amino acid is recognized based on the name and function of the formed protein which founded by alignment process on CCD (Conserved Domain Database) at NCBI. The formed proteins were then described by its functions and characters.

\section{Construction of ureC phylogenetics tree}

Deduced amino acid sequence were used for constructing ureC phylogenetics tree. The neighboring relative of each sequence was obtained from GenBank using BLASTP tool (www.blast.ncbi.nlm.nih.gov/Blast). The relative sequence was then aligned using ClustalW program. The phylogenetic tree was constructed using Neighbor-Joining method by MEGA7 program. Boostrap with 1000 replication was applied to evaluate the formed phylogenetics tree branches.

\section{RESULTS AND DISCUSSION}

\section{Urease screening}

The six $\mathrm{CaCO}_{3}$ forming bacteria isolates were able to hydrolyze urea. Figure 1 shows the color of Christensen urea agar media turned into cherish pink after 24 hours of incubation at $37^{\circ} \mathrm{C}$.

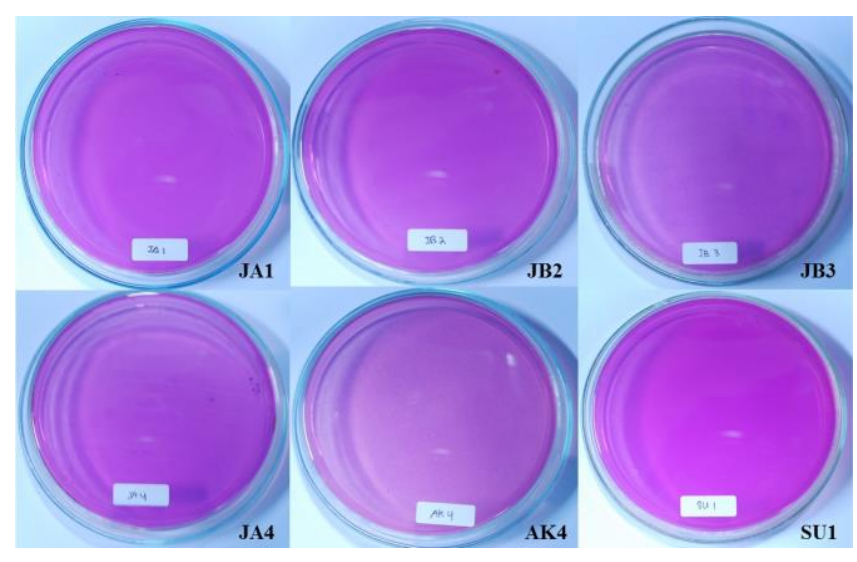

Figure 1. All tested bacterial isolates (JA1, JB2, JB3, JA4, AK4, and SU1) are capable to turn the medium color into cherish pink 


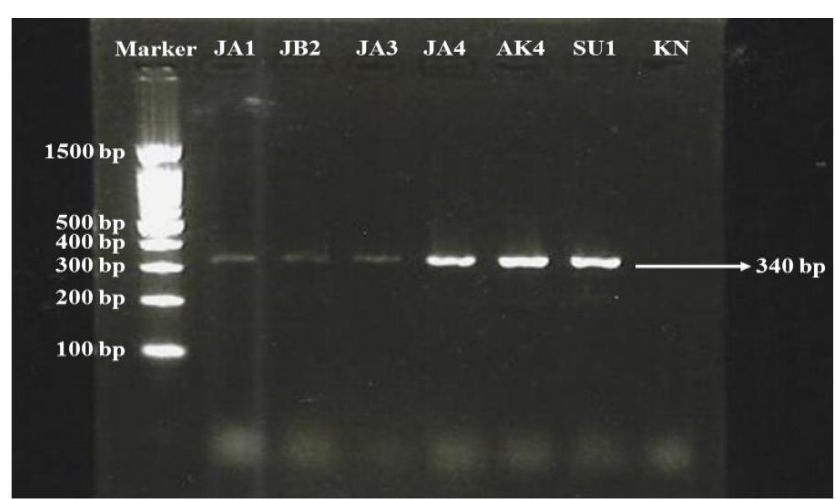

Figure 2. Electrophoresis result of ureC in $1.5 \%$ agarose gel. All of the tested isolates showed $340 \mathrm{bp}$ band. Promega ${ }^{\circledR}$ BenchTop $100 \mathrm{bp}$ was used as marker. * KN: Negative control

\section{Genomic DNA extraction and PCR result}

Electrophoresis results of ure $C$ detection showed that all isolates possess the ure $C$ in their genomic DNA. Figure 2 shows the molecular weight of the ure $C$ gene is $340 \mathrm{bp}$ (Reeds et al. 2001).

\section{Sequencing and $u r e C$ sequence analysis}

All sequences which evaluated with BLASTX are sequences encoding $\alpha$ sub-unit of urease protein. The amount of predicted deduced amino acid through BLASTX ranges from 90-107 amino acids. Meanwhile, the similarity analysis of amino acid sequence compared with amino acid sequences which deposited in NCBI database showed similarity value range from $88-100 \%$. The urease subunit $\alpha$ sequence from JB2 isolate possesses $100 \%$ similarity with the ureC $\alpha$ subunit gene from Lysinibacillus sphaericus B1-CDA (WP_054549252.1), whereas the amino acid sequence urease $\alpha$ subunit in JA1 isolates possess similarity of $88 \%$ (lowest) with $\alpha$ subunit ureC gene from Bacillus cihuensis FJAT-14515 (WP_028391929.1). The complete results are shown in Table 2.

\section{ure $C$ gene phylogenetic tree}

Phylogenetic tree of the ure $C$ in Figure 3 shows the bootstrap value varies between $36 \%-100 \%$. Phylogenetic tree branch considered to be consistent if it has bootstrap value above $70 \%$ (Hedges 1992). There is JB3 and JA4 sequence which possess bootstrap value below $70 \%$ with their relative sequence. All of our tested isolates belong to Firmicutes phylum and divided into two different families are Bacillales (genus Bacillus, Virgibacillus, and Lysinibacillus) and Planococcaceae (genus Sporosarcina). In the ure $C$ phylogenetic showed JA1 isolates had the closest relation with $B$. cihuensis, JB2 isolates with $L$. sphaericus, JB3 isolates with $V$. necropolis, JA4 isolates with Sporosarcina sp., AK4 isolates with Bacillus sp., and SU1 isolates with Bacillus lentus.

\section{Discussion}

The formation of $\mathrm{CaCO}_{3}$ can be induced through ureolytic bacterial activity, this material can be used as ingredient in paper, polymers, and anticorrosive paints industry (Rohaya et al. 2010; Hosada et al. 2003; Olad and Rashidzadeh 2008). Urea is a nitrogen source that can easily be hydrolyzed to form ammonia and is then assimilated into bacterial cell proteins formation (Wagner et al. 2010). Bacterial isolates namely JA1, JB2, JB3, JA4, $\mathrm{AK} 4$, and SU1 are ureolytic bacteria group, since they can turn the color of Christensen's medium into cherish pink. Hydrolyzed urea leads to ammonium ion accumulation, so that the medium alkalinity got increased. Phenol red is $\mathrm{pH}$ indicator that contained in the medium, when the medium alkalinity was increased, it will turn from yellow into cherish pink (Prescott 2002). Bacteria that capable to hydrolyze urea are easily found in various types of environment (Fujita et al. 2000).

Table 2. BLASTX result of $u r e C$ from NCBI

\begin{tabular}{|c|c|c|c|c|}
\hline Isolate & Protein name & The most similar sequence ureC & Identity & Similarity \\
\hline JA1 & Urease subunit alpha & $\begin{array}{l}\text { Bacillus cihuensis } \\
\text { FJAT-14515 (WP_028391929.1) }\end{array}$ & $84 / 95$ & $88 \%$ \\
\hline JB2 & Urease subunit alpha & $\begin{array}{l}\text { Lysinibacillus sphaericus } \\
\text { B1-CDA (WP_054549252.1) }\end{array}$ & 93/93 & $100 \%$ \\
\hline JB3 & Urease subunit alpha & $\begin{array}{l}\text { Virgibacillus necropolis } \\
\text { LMG } 19488 \text { (WP_089533948.1) }\end{array}$ & $84 / 92$ & $91 \%$ \\
\hline JA4 & Urease subunit alpha & $\begin{array}{l}\text { Sporosarcina sp. } \\
\text { HY08 (WP_067407747.1) }\end{array}$ & $89 / 90$ & $99 \%$ \\
\hline AK4 & Urease subunit alpha & $\begin{array}{l}\text { Bacillus sp. } \\
\text { FJAT-29937 (WP_066290964.1) }\end{array}$ & $101 / 107$ & $94 \%$ \\
\hline SU1 & Urease subunit alpha & $\begin{array}{l}\text { Bacillus lentus } \\
\text { NBRC16444 (WP_066141981.1) }\end{array}$ & $85 / 93$ & $92 \%$ \\
\hline
\end{tabular}




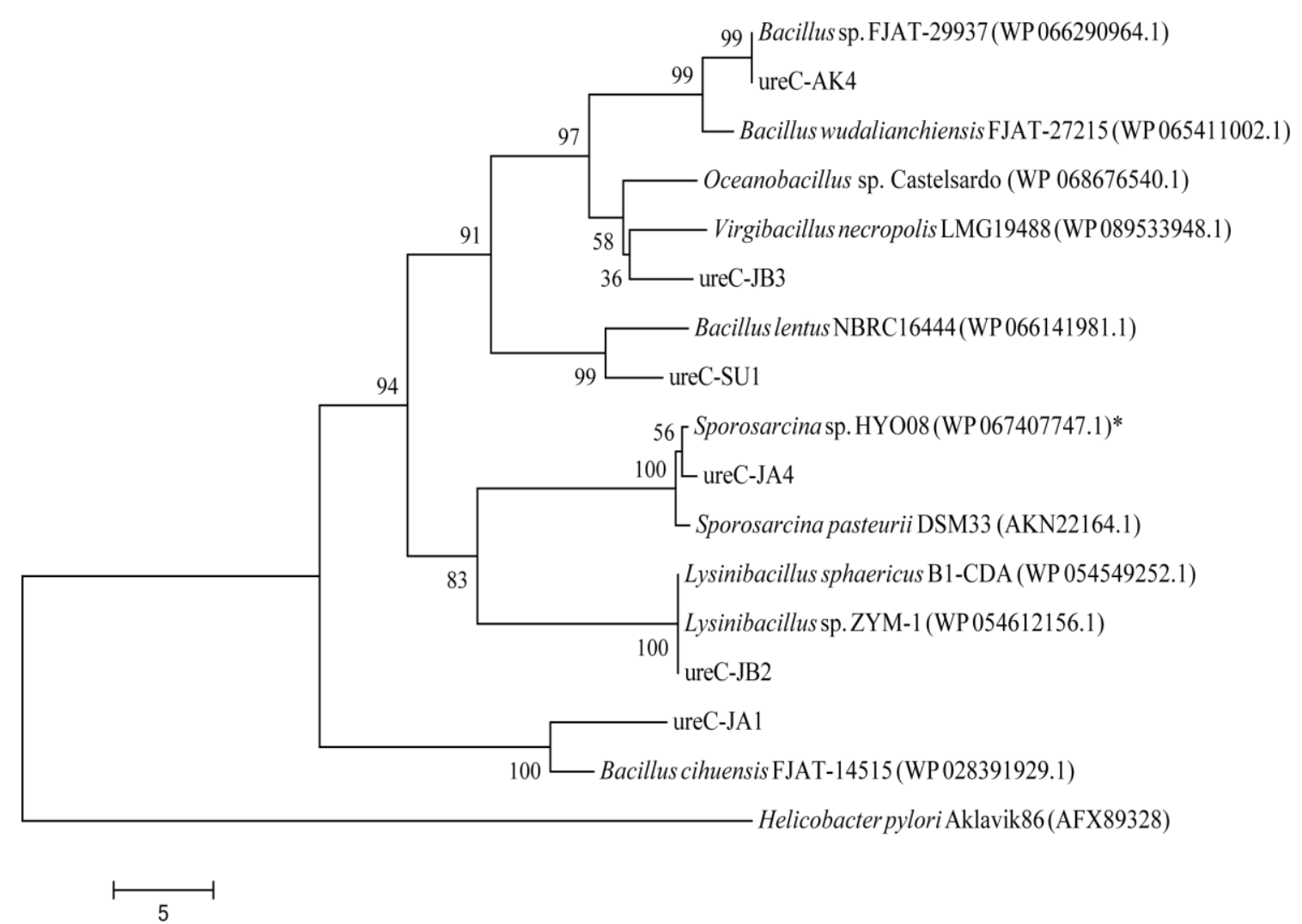

Figure 3. Phylogenetics tree from amino sequence which encoded by ureC gene from tested isolates and their relatives. Phylogenetic tree construction was performed by 1000 replication of bootstrap

All isolates showed positive results in the detection of ureC gene with $340 \mathrm{~kb}$ of DNA after electrophoresis on $1.5 \%$ agarose gel. The $340 \mathrm{~kb}$ DNA band showed the number of nucleotides which flanked by the ureC-F and ureC-R primers. This primer was made using CODEHOP program through aligning of $u r e C$ sequences from various bacteria (Reeds et al. 2001). The $u r e C$ gene was chosen as urease coding gene marker, since ureC gene encodes the $\alpha$ subunit which is the active site of urease and it has function in binding of nickel, substrate, and catalytic metals (Mobley et al. 1995). The BLASTX program suggest the possible amino acids which can be formed from the sequence of ureC gene from those isolates; determine the name of the protein which formed from the amino acid alignment test in Conserve Domain Database; and determine the similarity of tested amino acid sequences with amino acids that deposited in protein databases (NCBI). Analysis of the ureC was carried out by translating into amino acid sequences because of the similarity of ureC at the nucleotide level is lower than at protein level, due to the degeneration of its genetic code (Reeds 2001). BLASTP results showed that the amino acid sequence formed has similar sequences with uraolytic bacteria that have been known to induce the formation of $\mathrm{CaCO}_{3}$ such as Bacillus, Lysinibacillus, Virgibacillus, and Sporosarcina (Sarada et al. 2009; Krishnapriya et al. 2015; Silva-Castro et al. 2015; Dhami et al. 2013).
Even the results of ureC and 16S rRNA phylogeny analysis showed genus congruency, but there was still difference in result on JB3 isolates which showing the closest similarity with genera Lysinibacillus by ureC analysis (Utomo 2018). The different results from gene barcode (16S rRNA) and ureC analysis might be caused by horizontal gene transfer (HGT) phenomenon among ureolytic bacteria, instead of genetic transmission into the next generation bacteria cell (Keeling et al. 2008). Since this gene undergoes horizontal gene transfer, it might not reflect the actual composition of bacteria community. However, Su et al. (2013) state that this gene may be used better for understanding ureolytic bacteria strain wherein this ability is not possessed by the 16S rRNA gene.

\section{ACKNOWLEDGEMENTS}

This research was supported by the Direktorat Riset dan Pengabdian kepada Masyarakat (DRPM) fund, through the Institut Teknologi Sepuluh Nopember (ITS) Surabaya, contract number 879/PKS/ITS/2018.

\section{REFERENCES}

Andrews RK, Brakeley RL, Zenner B. 1984. Urea and urease. In: Advance in inorganic biochemistry. Elsevier Science, New York. 
Atlas RM. 2010. Handbook of Microbiological Media. 4th ed. Taylor \& Francais Group, UK.

Benini S, Repneiwski WR, Wilson KS, Meletti S, Ciurli S, Mangani S 1999. A new proposal of urease mechanism based on the crystal structure of the native and inhibited enzyme from Bacillus pasteurii: why urea hydrolysis costs two nickel. Structure 7: 205-216.

Caccamo D, Maugeri TL, Gugliandolo C. 2001. Identification of thermophilic and marine bacilli from shallow thermal vents by restriction analysis of their amplified 16S rDNA. J Appl Microbiol 50: 2009-2012.

Castanier S, Le Metayer-Levrel G, Perthuisot JP. 1999. Ca-carbonates precipitation and limestone genesis-the microbiogeologist point of view. Sediment Geol 126: 9-23.

Chunxiang Q, Jianyun W, Ruixing W, Liang C. 2009. Corrosion protection of cement-based building materials by surface deposition of $\mathrm{CaCO}_{3}$ by Bacillus pasteurii. Mater Sci and Eng C 29: 1273-1280.

De Jong JT, Mortensen BM, Martinez BC, Nelson DC. 2010. Biomediated soil improvement. Ecol Eng 136: 197-210.

Dhami NK, Reddy MS, Mukherjee A. 2013. Biomineralization of calcium carbonate polymorphs by the bacterial strains isolated from calcareous sites. J Microbiol Biotechnol 23 (5): 707-714.

Fujita Y, Ferris FG, Lawson RD, Smith RW. 2000. Calcium carbonate precipitation by ureolytic subsurface bacteria. Geomicrobiol J 17 (4): 305-318.

Gresham TL. T, Sheridan PP, Watwood ME, Fujita Y, Colwell SF. 2007. Design and validation of ureC-based primers for groundwater detection of urea-hydrolyzing bacteria. Geomicrobiol J 24: 353-364.

Hammes F, Boon N, de Villiers J, Verstraete W, Siciliano SD. 2003. Strain-specific ureolytic microbial calcium carbonate precipitation. Appl Environ Microbiol 69 (8): 4901-4909.

Harley, Prescott LM. 2002. Laboratory Exercise in Microbiology. $5^{\text {th }}$ ed. Mc Graw Hill, USA.

Hedges SB. 1992. The number of replications needed for accurate estimation of the bootstrap $\mathrm{P}$ value in phylogenetic studies. Mol Biol Evol 9 (2): 366-369.

Jeong Y, Hargis CW, Chun S, Moon J. 2017. Effect of calcium carbonate fineness on calcium sulfoaluminate-belite cement. Materials 10 (900): 1-18.

Jimenez-Lopez C, Jroundi F, Pascolini C, Rodriguez-Navarro C, PinarLarrubia G, Rodriguez-Gallego M, Gonzalez-Munoz MT. 2008 Consolidation of quarry calcarenite by calcium carbonate precipitation induced by bacteria activated among the microbiota inhabiting the stone. Int. Biodeterior Biodegrad 62 (4): 352-363.

Joners BD, Mobley HL. 1989. Proteus mirabilis urease: nucleotide sequence determination and comparison with jack bean urease. J Bacteriol 171 (12): 6414-6422.
Keeling PJ, Palmer JD. 2008. Horizontal gene transfer in eukaryotic evolution. Nature Rev Genet 9 (8): 605.

Krishnapriya S, Babu DLV, Arulraj PG. 2015. Isolation and identification of bacteria to improve the strength of concrete. Microbiol Res 174: 48-55.

Mobley HL, Island MD, Hausinger RP. 1995. Molecular biology of microbial urease. Microbiol Rev 9: 451-480.

Olad A, Rashidzadeh A. 2008. Preparation and characterization of polyaniline/ $\mathrm{CaCO}_{3}$ composite and its application as anticorrosive coating on iron. Iran J Chem Eng 5 (2): 45-54.

Ozen I, Simsek S, Eren F. 2013. Production and Characterization of Polyethylene/Calcium Carbonate Composite Materials by Using Calcium Carbonate Dry and Wet Coated With Different Fatty Acids. Polymers \& Polymer Composites 21 (3): 183-188.

Prescott H. 2002. Laboratory exercise in Microbiology. 5th ed. McGraw Hill, New York.

Reeds KE. 2001. Restriction enzyme mapping of bacterial urease genes: using degenerate primers to expand experimental outcomes. Biochem and Mol Biol Educ 29: 239-244.

Rohaya O, Sarani Z, Chin HC, Ainun Z, Nasharuddin I. 2010. Mechanical and optical properties of $\mathrm{CaCO}_{3}$ lumen-loaded paper: Effect of polyethyleneimine and alum. Sains Malaysiana 39: 435-439.

Sarada D, Choonia HS, Sarode DD, Lele SS. 2009. Biocalcification by Bacillus pasteurii urease: a novel application. J Ind Microbiol Biotechnol 36: 1111-1115.

Silva-Castro GA, Uad I, Gonzalez-Martinez A, Rivadeneyra A, GonzalezLopez J, Rivadeneyra MA. 2015. Bioprecipitation of calcium carbonate crystal by bacteria isolated from saline environments grown in culture media amended with seawater and real brine. BioMed Res Intl 2015: 1-12.

Skinner HCW, Ehrlich H. 2014. Biogeochemistry. In: Holland HD, Turekian, KK, (eds) Treatise on Geochemistry. 2nd ed. Elsevier, Netherlands.

Su J, Jin L, Jiang Q, Sun W, Zhang F, Li Z. 2013. Phylogenetically diverse ureC genes and their expression suggest the urea utilization by bacterial symbionts in marine sponge Xestospongia testudinaria. PLoS One 8 (5): e64848. DOI: 10.1371/journal.pone.0064848.

Utomo MAP. 2018. Carbonatogenic Bacteria as Biocement for Alternative Cracks Repairment on Concrete [Thesis]. Institut Teknologi Sepuluh Nopember, Surabaya. [Indonesian]

Wagner JJ, Engle TE, Bryant T. C. 2010. The effect of rumen degradable and rumen undegradable intake protein of feedlot performance and carcass merit in heavy yearling steers. J Anim Sci 88: 1073-1081.

Wei S, Cui H, Jiang Z, Liu H, He H, Fang N. 2015. Biomineralization process of calcite induced by bacteria isolated from marine sediments. Brazilian J Microbiol 46 (2): 455-464. 